\section{Erratum}

https://doi.org/10.11646/zootaxa.5020.3.12

http://zoobank.org/urn:1sid:zoobank.org:pub:CBE8556B-C524-4DA8-BF94-3BB704375526

\title{
JOSEPH MARLOW, JAMES J. BELL, MEGAN SHAFFER, ABDUL HARIS \& CHRISTINE H.L. SCHÖNBERG (2021) Bioeroding sponge species from the Wakatobi region of southeast Sulawesi, Indonesia. Zootaxa, 4996: 001-048.
}

The figure legend for Figure 1 on page 3 should read as:

Map of sampling locations where bioeroding sponges were extracted. Left inset map shows the position of the Islands of Kaledupa and Hoga within the wider Wakatobi. Sites 'Buoy $1 \&$ 3', 'Kaledupa 1' and 'Kaledupa Double Spur', 'Pak Kasim's', 'Ridge 1' and 'Sampela 1' are abbreviated as B1, B3, K1, KDS, PK, R1 and S1, respectively.

Instead of:

Map of sampling locations where bioeroding sponges were extracted. Right inset map (source https://commons. wikimedia.org/) and red dot indicate the position of the Wakatobi within the Indonesian region. Left inset map further shows the position of the Islands of Kaledupa and Hoga within the wider Wakatobi. Sites 'Buoy 1 \& 3', 'Kaledupa 1' and 'Kaledupa Double Spur', 'Pak Kasim's', 'Ridge 1' and 'Sampela 1' are abbreviated as B1, B3, $\mathrm{K} 1, \mathrm{KDS}, \mathrm{PK}, \mathrm{R} 1$ and $\mathrm{S} 1$, respectively. 